\title{
О МИНЕРАЛЬНЫХ ОБРАЗОВАНИЯХ ПО ИК-СПЕКТРАМ ГОРЮЧЕГО СЛАНЦА-КУКЕРСИТА (КЕРОГЕНА-90)
}

\begin{abstract}
Hilja TAAL, H. PALMRE. MINERAALSETE KOMPONENTIDE MOJUST KUKERSIITPOLEVKIVI
\end{abstract} (KEROGEEN-90) INFRAPUNASTELE NEELDUMISSPEKTRITELE

Hilja TAAL, H. PALMRE. THE INFLUENCE OF MINERAL SUBSTANCE ON INFRARED ABSORPTION SPECTRA OF OIL SHALE

По данным минерало-петрографических исследований, в органическом веществе (OB) горючего сланца присутствуют незначительные количества минеральных частиц (кальцита, марказита, кварца, пидрослюды и др.) [']. Идентификация минеральных образований (MO) с бо́льшим содержанием ОВ горючего сланца путем термических исследований $\left[{ }^{2,3}\right]$ - сложная задача. Подробно иселедованы ИК-спектры поглощения керогена [4]. Установлено, что все полосы поглощения соответствуют только колебаниям ОВ. В настоящее время ИК-спектры чистых минералов изучены достаточно полно $[5,6,8]$, и представляется возможной их диагностика по ИК-спектрам поглощения.

Нами исследовалось влияние МО на ИК-спектры поглощения керогена-90, выделенного флотационным методом. Учитывая, что важной диагностической характеристикой MO является поглощение в области поглощения органических групп, нами представлены ИК-спектры природного горючего сланца, керогена-90 и керогена-90, нагретого до $480^{\circ} \mathrm{C}$ (МО керогена-90) с целью выжигания ОВ [3].

Образцы в виде таблеток с $\mathrm{KBr}$ сняты на инфракрасном спектрофотометре UR-10 в диапазоне $3200-450$ см ${ }^{-1}$. Для оценивания влияния колебаний МО на ИК-спектр керогена-90 изготовлялись таблетки из МО керогена-90 с добавлением $\mathrm{KBr}$ в таком количестве, чтобы концентрация $\mathrm{MO}$ соответствовала концентрации $\mathrm{MO}$ в керогене-90.

Основными полосами поглощения (см. рисунок), присутствующими во всех спектрах, являются равные по интенсивности широкие размытые полосы около $1040 \mathrm{~cm}^{-1}$. Так как $\mathrm{Si}-\mathrm{O}$-связь общая для всех силикатов и глинистых минералов, можно считать, что сильные абсорбционные полосы в районе 1105-963 cм ${ }^{-1}$ обусловлены, главным образом, валентными колебаниями $\mathrm{Si}-\mathrm{O}\left[{ }^{6}\right]$. Глинистые минералы обнаруживают сходные спектры с силикатами, и, кроме того, полоса глинистых минералов около $1000 c M^{-1}$ имеет дублет (у каолинита $-918 c M^{-1}$, у монтмориллонита $920\left(M^{-1}\right)$, что связано с колебаниями структурных гидроксильных групп. В спектре MO керогена-90 (рисунок, кривая 3) последнее колебание отсутствует, возможно, из-за маленькой концентрации глинистых минералов в исследуемых нами пробах или из-за дегидратации проб при нагревании. По литературным данным [7], это колебание исчезает после нагревания пробы до температуры около $500^{\circ}$.

Заметную роль в ИК-спектре поглощения МО керогена-90 играют пики поглощения около $1155-1120,680$ и дублет $615,595 \mathrm{~cm}^{-1}$. 


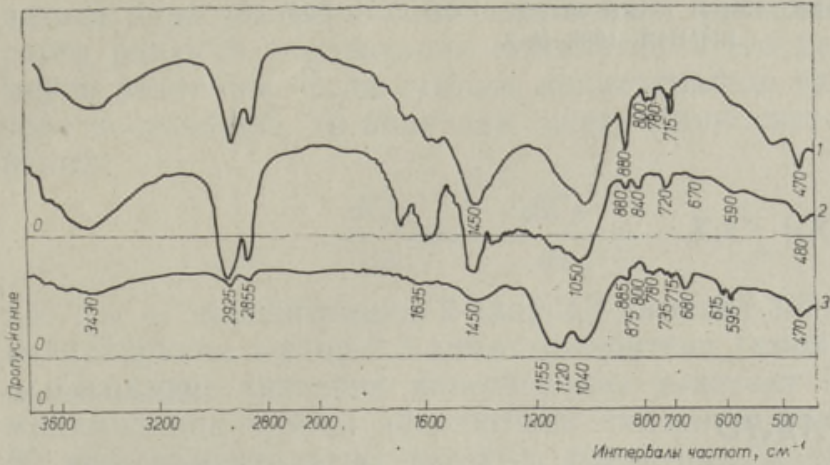

Инфракрасные спектры: 1 - природного горючего сланца-кукерсита; 2 флотационного концентрата - керогена-90; 3 флотационного концентрата, нагретого до $480^{\circ} \mathrm{C}$.

Эти колебания отнесены нами к несимметричным колебаниям иона $\mathrm{SO}_{4}^{2-}$ (а именно - к ангидриту). Возникновение таких интенсивных полос поглощения вызвано не только дегидратацией гипса (в спектре керогена-90 слабые полосы около 670, 590 см ${ }^{-1}-$ см. рисунок, кривые 1,2$)$, но и, вероятно, образованием ангидрита в результате разрушения определенных химических связей органо-минеральных соединений при сгорании ОВ. Второстепенное значение имеют слабые дублеты полос поглощения 885,875 и $730,715 \mathrm{~cm}^{-1}$. Первые принадлежат несимметричным колебаниям, вторые (а также $1450 \mathrm{~cm}^{-1}$ ) - симметричным колебаниям иона $\mathrm{CO}_{3}^{2-}\left[{ }^{8}\right]$, возможно, - в минералах кальцит и доломит. Часть спектра, не отнесенная ни к карбонатным, ни к сульфатным полосам, имеет тот же характер, что и спектр биогенного кремнезема, полученный при изучении диатомовых водорослей четвертичных радиолариевых илов [9]. Этот спектр выделяется лишь приоутствием колебания связи $\mathrm{Si}-\mathrm{O}-\mathrm{Si}$ (дублет около $800 \mathrm{~cm}^{-1}$ ), что указывает, видимо, на высокую дисперсность кремнезема [ $\left.{ }^{10}\right]$.

Таким образом, исследуемый нами кероген-90 содержит минеральные примеси в виде кальцита, доломита и кремнезема, их колебания осложняют идентифицирование органических структур горючего сланцакукерсита по ИК-спектрам поглощения.

\section{Л И ТЕ Р А Т У Р А}

1. Д ил акторский Н. Л. К вопросу о строении керогена. - Изв. АН ЭССР, сер. физ.-мат. и техн. н., 1960, т. 9. № 2, 2. 130-133.

2. Л уцковская Н. Л., К аз а ков Е. И. Комплексное термографическое и химическое исследование эстонского сланца-кукерсита. - Изв. АН ЭССР, сер. физ.-мат. и техн. Н., 1956, т. 5, № 2, с. $129-139$.

3. Т а а л X., Сюгис-Рулли А., Палмре X. O дериватограммах горючего сланца-кукерсита. - Изв. АН ЭССР, хим., 1978, т. 27, № B, с. 197-199.

4. Grassely, Gy., Heté ny i, M., Ag ócs, M. Contributions to the alkaline nermanganate oxidation of the kerogen, lignite and peat. - Acta Mineral.-Petrograph., 1973 , v. 21, N 1, p. 55-711.

5. Mo e n ke, H. Mineralspektren. - In: Dtsch. Akad. Wiss. Berlin, Akademie-Verlag, 1962.

6. Пл юснин а И. И. Инфракрасные спектры силикатов. М., 1967.

7. Л и т л Л. Инфракрасные спектры адсорбированных молекул. М., 1969, с. $407-418$.

8. Н акамото К. Инфракрасные спектры неорганических и координационных соединений. М.. 1966.

9. Плюснина И. И., Л евитин М. А. Кристаллохимия минералов и геологические проблемы. М., 1975 , с. $189-192$.

10. Болд ы р в А. И. Инфракрасные спектры минералов. М., 1976. 